\title{
A large-scale field study examining effects of exposure to clothianidin seed-treated canola on honey bee colony health, development, and overwintering success
}

In summer 2012, we initiated a large-scale field experiment in southern Ontario, Canada, to determine whether exposure to clothianidin seed-treated canola (oil seed rape) has any adverse impacts on honey bees. Colonies were placed in clothianidin seed-treated or control canola fields during bloom, and thereafter were moved to an apiary with no surrounding crops grown from seeds treated with neonicotinoids. Colony weight gain, honey production, pest incidence, bee mortality, number of adults, and amount of sealed brood were assessed in each colony throughout summer and autumn. Samples of honey, beeswax, pollen, and nectar were regularly collected, and samples were analyzed for clothianidin residues. Several of these endpoints were also measured in spring 2013. Overall, colonies were vigorous during and after the exposure period, and we found no effects of exposure to clothianidin seed-treated canola on any endpoint measures. Bees foraged heavily on the test fields during peak bloom and residue analysis indicated that honey bees were exposed to low levels $(0.5-2 \mathrm{ppb})$ of clothianidin in pollen. Low levels of clothianidin were detected in a few pollen samples collected toward the end of the bloom from control hives, illustrating the difficulty of conducting a perfectly controlled field study with free-ranging honey bees in agricultural landscapes. Overwintering success did not differ significantly between treatment and control hives, and was similar to overwintering colony loss rates reported for the winter of 2012-2013 for beekeepers in Ontario and Canada. Our results suggest that exposure to canola grown from seed treated with clothianidin poses low risk to honey bees. 
1 Research Article

2 A large-scale field study examining effects of exposure to clothianidin seed-

3 treated canola on honey bee colony health, development, and overwintering

4 success

5 G. Christopher Cutler (1)*, Cynthia D. Scott-Dupree (2), Maryam Sultan (2),

6 Andrew D. McFarlane (2), Larry Brewer (3)

7 (1)Department of Environmental Sciences, Dalhousie University Agricultural

8 Campus, Truro, NS, Canada

9 (2)School of Environmental Sciences, University of Guelph, Guelph, ON,

10 Canada

11 (3) Smithers Viscient, Carolina Research Center, Snow Camp, NC, United

$12 \quad$ States

13 *Corresponding author: Tel: 1-902-896-2471, Fax: 1-902-893-1404, email:

14 chris.cutler@dal.ca 


\section{ABSTRACT}

16 In summer 2012, we initiated a large-scale field experiment in southern

17 Ontario, Canada, to determine whether exposure to clothianidin seed-treated

18 canola (oil seed rape) has any adverse impacts on honey bees. Colonies

19 were placed in clothianidin seed-treated or control canola fields during

20 bloom, and thereafter were moved to an apiary with no surrounding crops

21 grown from seeds treated with neonicotinoids. Colony weight gain, honey

22 production, pest incidence, bee mortality, number of adults, and amount of

23 sealed brood were assessed in each colony throughout summer and autumn.

24 Samples of honey, beeswax, pollen, and nectar were regularly collected, and

25 samples were analyzed for clothianidin residues. Several of these endpoints

26 were also measured in spring 2013. Overall, colonies were vigorous during

27 and after the exposure period, and we found no effects of exposure to

28 clothianidin seed-treated canola on any endpoint measures. Bees foraged

29 heavily on the test fields during peak bloom and residue analysis indicated

30 that honey bees were exposed to low levels $(0.5-2 \mathrm{ppb})$ of clothianidin in

31 pollen. Low levels of clothianidin were detected in a few pollen samples

32 collected toward the end of the bloom from control hives, illustrating the

33 difficulty of conducting a perfectly controlled field study with free-ranging

34 honey bees in agricultural landscapes. Overwintering success did not differ

35 significantly between treatment and control hives, and was similar to

36 overwintering colony loss rates reported for the winter of 2012-2013 for

37 beekeepers in Ontario and Canada. Our results suggest that exposure to 
38 canola grown from seed treated with clothianidin poses low risk to honey

39 bees.

40 Key words. honey bees, clothianidin, neonicotinoid, seed-treatment, canola,

41 pollinators

\section{INTRODUCTION}

43 The neonicotinoid class of insecticides - which includes imidacloprid,

44 acetamiprid, clothianidin, thiamethoxam, thiacloprid, dinotefuran and

45 nitenpyram - are considered an important tool for pest management in many

46 agricultural systems. As of 2006 , this insecticide class accounted for

47 approximately \$US 1.56 billion worldwide, representing nearly $17 \%$ of the

48 global insecticide market (Jeschke \& Nauen, 2008). When first introduced in

49 the mid-1990s, neonicotinoids were well-received by pesticide regulators,

50 ecotoxicologists, and farmers, owing to their novel mode of action, efficacy

51 against multiple pests, and selectivity for insects over vertebrates (Jeschke \&

52 Nauen, 2008; Matsuda et al., 2001). In addition, the systemic activity of

53 neonicotinoids allows them to be applied to soil or seeds at low rates,

54 providing protection to crops in their more vulnerable early stages. This

55 reduces the number of foliar insecticide applications required, which are

56 applied at much greater application rates and generally pose more hazard to

57 non-target organisms.

58 There is much concern, however, regarding potential risks of

59 neonicotinoids to pollinators, mainly bees (Apoidea). Several neonicotinoids

60 are highly toxic to bees (Iwasa et al., 2004; Scott-Dupree, Conroy \& Harris, 
$61 \underline{2009}$ ) and mitigation measures are needed to minimize pollinator exposure

62 where identified hazards may occur. For example, for foliar applications of

63 compounds in the nitroguanidine class of neonicotinoids (imidacloprid,

64 thiamethoxam, clothianidin, and dinotefuran), there are warnings on product

65 labels in North America not to apply or allow them to drift on to flowering

66 crops or weeds if bees are foraging in the treated area. To minimize exposure

67 to contaminated dust generated during the planting of neonicotinoid treated

68 seeds, which can result in bee-kill incidents ( $\underline{\text { Cutler, Scott-Dupree \& Drexler, }}$

69 2014), efforts are being made to improve the seed treatment process, modify

70 planting equipment, and encourage best management practices among

71 growers and beekeepers to reduce pollinator risk from exposure to

72 neonicotinoid contaminated dust from treated seed (Nuyttens et al., 2013;

73 PMRA, 2013).

$74 \quad$ There is perhaps more debate regarding potential risks to bees through

75 feeding on nectar or pollen from plants grown from seed treated with

76 neonicotinoids. Several studies have found that neonicotinoids can cause

77 various adverse chronic/sublethal effects on honey bees (Apis spp.) and

78 bumble bees (Bombus sp.). These studies have been important in

79 demonstrating different ways toxicity can occur, and the potential hazards

80 neonicotinoids pose to pollinators. Some have argued, however, that such

81 studies have used unrealistic exposure scenarios (Campbell, 2013; Cresswell,

82 2013; Cresswell \& Thompson, 2012; EFSA, 2012b; Walters, 2013), either

83 subjecting bees to doses that are higher than those typically experienced in

84 field (Gill, Ramos-Rodriguez \& Raine, 2012; Henry et al., 2012), or subjecting 
85 bees in the laboratory exclusively to food spiked with neonicotinoids for

86 prolonged periods (Whitehorn et al., 2012). On the other hand, semi-field

87 (field cage) and field studies have found that individual bees and colonies are

88 not adversely impacted when foraging on neonicotinoid seed-treated crops

89 (Cutler \& Scott-Dupree, 2007; Cutler \& Scott-Dupree, 2014; Nguyen et al.,

90 2009; Pilling et al., 2013; Pohorecka et al., 2012; Schmuck \& Keppler, 2003;

91 Schmuck et al., 2001; Schneider et al., 2012; Tasei, Ripault \& Rivault, 2001;

92 Thompson et al., 2013).

93 Clothianidin is used on millions of hectares of canola (Brassica napus

94 L.) in western Canada and elsewhere, mainly to provide protection against

95 early-season defoliators such as flea beetles (Phyllotreta spp.). There is

96 concern by some scientists, beekeepers, legislators, and members of the

97 general public that bees foraging on clothianidin seed-treated canola will

98 suffer acute or chronic effects that compromise colony health. Here we

99 present results of a large-scale field study done in 2012-2013 in southern

100 Ontario, Canada, undertaken to determine whether or not exposure to

101 clothianidin seed-treated canola has any adverse impacts on honey bees

102 (Apis mellifera L). We examined numerous colony endpoints before, during,

103 and after treatment exposure in the field.

\section{MATERIALS AND METHODS}

105 This research was conducted in accordance with the Organization for

106 Economic Cooperation and Development Principles of Good Laboratory

107 Practice (EPA, 1989; OECD, 1999). The experimental design was developed 
108 by GCC, CDSD, LB, in consultation with personnel from Bayer CropScience,

109 the Health Canada Pest Management Regulatory Agency, and the United

110 States Environmental Protection Agency. No claim of confidentiality is made

111 for any information contained in this study on the basis of its falling within

112 the scope of the Federal Insecticide, Fungicide, and Rodenticide Act, FIFRA

113 Section $10(d)(1)(A),(B)$, or $(C)$.

\section{Seed Treatment}

115 Clothianidin (CAS No.: 205510-53-8) was applied to canola seed as Prosper

$116 \mathrm{FX}^{\circledR}$ formulation (20.4\% clothianidin, $0.5 \%$ trifloxystrobin, 3.6\% carbathiin

117 and $0.4 \%$ metalaxyl) at the Bayer CropScience Seed Technology Center

118 (Research Triangle Park, NC). Seed was treated at the target label rate of

$1191400 \mathrm{ml}$ Prosper per $100 \mathrm{~kg}$ of seed. An equal amount of seed was treated

120 with a control formulation that contained trifloxystrobin, carbathiin, and

121 metalaxyl at their registered label rates, but did not contain clothianidin.

122 Seed was shipped to the Bayer CropScience Canada Rockwood Research

123 Farm (Rockwood, ON) and stored in plastic bins (separate seed bin for each

124 treatment) at temperatures that ranged from $3.9-27.4^{\circ} \mathrm{C}$. Subsequent

125 analysis of treated seed confirmed that the targeted seed treatment rate was

126 met, at $91 \%$ of the nominal treatment rate (maximum allowed on the label),

127 which is within the acceptable range of error of the analytical method.

\section{Field Sites and Planting}


129 Fields under the ownership of cooperating farmers were used in this

130 experiment and their consent was granted to access study sites, and to apply

131 pesticides and fertilizers. Application of pesticides and fertilizer complied

132 with all government and manufacturer regulations.

133 Ten fields in southwest Ontario, Canada, suitable for growing spring

134 canola were chosen. Fields were in Brant (1), Oxford (1), Waterloo (5),

135 Wellington (2), and Wentworth (1) counties within an area of approximately

$13660 \times 65 \mathrm{~km}$. To our knowledge, which involved consultation with growers

137 throughout the region and ground-truthing the area around the test sites, no

138 other canola was being grown within foraging distance of our experimental

139 fields. Fields were located a minimum of $10 \mathrm{~km}(6 \mathrm{mi})$ apart and in areas

140 which, in the previous 12 months, had not received applications of

141 neonicotinoids such as clothianidin (Poncho, Titan, and Prosper), imidacloprid

142 (Admire, Gaucho, Alias, Grapple, and Stress Shield), thiacloprid (Calypso),

143 acetamiprid (Assail), or thiamethoxam (Cruiser, Actara, and Helix). Fields

144 that had been planted with wheat the previous year were chosen to minimize

145 the possibility that selected study fields had received neonicotinoid

146 treatments in the previous year. In southern Ontario, only a very small

147 percentage of wheat is grown from seed treated with neonicotinoids and

148 these wheat fields would have been planted the previous fall (2010). Thus,

149 the time since any previous neonicotinoid treatments had been made on test

150 fields to the start of the study was at least 1.5 years.

151 All sites received $400 \mathrm{~kg} / \mathrm{ha}$ of fertilizer ( $28 \% \mathrm{~N}, 5.6 \% \mathrm{P}, 7 \% \mathrm{~K}, 8.4 \% \mathrm{~S})$,

152 applied with a broadcast spreader and were prepared for planting with a 


\section{PeerJ Reviewing Manuscript}

153 McFarlane Reel Disk. Five field sites selected at random were planted as

154 "control" fields and the other five sites were planted as "clothianidin"

155 (treatment) fields. All fields were planted over three days on 10-12 May

156 2012. Each site was planted with approximately 2 ha ( 5 acres; range $=2.00$

$157-2.19$ ha) canola according to local agronomic practices. The seeder was

158 calibrated to deliver $5.6 \mathrm{~kg}$ canola seed/ha (5 Ibs/acre), which ensured a high

159 number of plants and an abundance of blooms on which bees could forage.

160 All sites were treated equally with Liberty ${ }^{\circledR}$ 200SN (glufosinate ammonium)

161 for weed control and Decis ${ }^{\circledR} 5 \mathrm{EC}$ (deltamethrin) for early season flea beetle

162 control. The interval between the last Decis 5EC application and the time

163 when hives were first placed at the test fields was at least 30 days.

\section{Colony Preparation and Management}

165 Prior to placement in canola plots on the study sites, 44 honey bee colonies

166 were maintained at a spring apiary located at the Arkell Agricultural Research

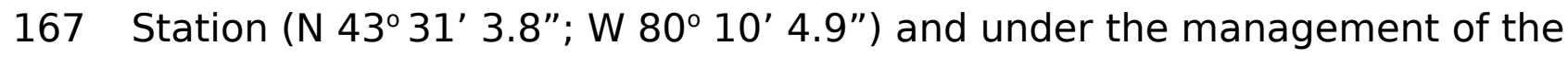

168 Honey Bee Research Facility (HBRF), University of Guelph, Guelph, Ontario.

169 Forty of these colonies were used in the study, and four were maintained as

170 spares. Each colony consisted of a single brood chamber measuring $24 \mathrm{~cm}$

$171\left(95 / 8^{\prime \prime}\right)$ deep, containing 9 frames and one follower board to replace the $10^{\text {th }}$

172 frame. The follower board in the brood chamber maintained the 10-frame

173 spacing typical of commercial colonies, while facilitating the frequent colony

174 assessments conducted during the study by allowing more working space in

175 the brood chamber. A single shallow empty honey super, measuring $16.5 \mathrm{~cm}$ 
$176\left(65 / 8^{\prime \prime}\right)$ deep and containing 9 frames with plastic foundation, was placed

177 above the brood chamber. Queen bees were provided by HBRF and all were

178 of the same lineage and approximately the same age. A queen excluder was

179 placed between the brood chamber and honey super to confine the queen to

180 the brood chamber. Colonies were adjusted for strength, as necessary, prior

181 to being moved to the canola fields. The strength adjustments established

182 similar quantities of food stores (pollen and nectar), sealed brood, and adults

183 in each colony.

184 Colonies also were assessed for presence of Varroa mite (Varroa

185 destructor), tracheal mite (Acarapis woodi), American foulbrood (AFB;

186 Paenibacillus larvae), European foulbrood (EFB; Melissococcus plutonius),

187 Nosema spp. (N. apis and/or N. ceranae), and chalkbrood before placement in

188 canola fields (Shimanuki \& Knox, 2000). Hives infected with diseases as

189 determined during the initial hive assessments were not used in the study.

190 Disease and parasite analyses were conducted again after removal from

191 canola, and during spring 2013 assessments. Colonies were treated with

192 Oxysol ${ }^{\circledR}$ (Oxytetracycline $\mathrm{HCL}$ ) mixed with powdered sugar in early spring of

1932012 and in early October 2012 to prevent EFB/AFB. To treat for Varroa

194 mites, hives received Apivar ${ }^{\circledR}$ (Amitraz) strips in early October of 2012.

195 These medications and acaricides were applied before and after the field

196 (canola) phase of the study. No medications were applied to hives while they

197 were in test fields. All study colonies received equal mite/disease treatment,

198 even when threshold levels of these pests were not present in some colonies.

199 Pest and disease status of colonies were assessed and recorded during hive 
200 assessments, which were conducted during 2012 on day $-4,7,14,21,42,63$,

201 and 84, and during spring 2013 assessment.

202 Honey supers were added to or removed from colonies as needed (i.e.

203 removed when they were full of honey). Brood boxes and honey supers were

204 weighed and labeled to facilitate accurate colony-component cross-

205 referencing and accurate assessment of productivity by weight.

\section{Colony Transport and Placement}

207 A $7 \times 7$ m clearing was mowed in the middle of each canola field to

208 accommodate four colonies. The central clearing was vehicle accessible via

209 a laneway running from the edge of the field on one side to the clearing.

210 When $\geq 25 \%$ of the canola was in bloom on test fields (determined by visual

211 estimation), colonies were moved in. The presence of $25 \%$ canola bloom

212 ensured that bees would not forage off site, as would occur if colonies were

213 moved to fields before bloom. Colonies were moved by pick-up truck into the

214 canola fields during the nights of 25-26 (16 colonies), 26-27 (16 colonies),

215 and 27 (8 colonies) June, 2012. Colonies were randomly assigned to fields.

216 The first full day colonies were in canola fields was designated Day 0. Four

217 colonies were positioned in the central clearing of each field so that the

218 entrances of the colonies faced NW, NE, SE and SW.

219 Colonies were removed from study fields after 14 days and transported

220 during darkness on the nights of 10-11, 11-12, and 12-13 July, 2012 to an

221 isolated apiary. It was intended that at least $25 \%$ of canola blooms would be

222 remaining in the fields at the time colonies were moved out of the canola 
223 fields, in order to minimize foraging of bees off site. However, due to

224 unusually high daily temperatures and drought conditions, some canola fields

225 were below $25 \%$ bloom at the time of colony removal. The isolated apiary

226 was located at the Land Forces Central Area Training Facility (LFCATF)

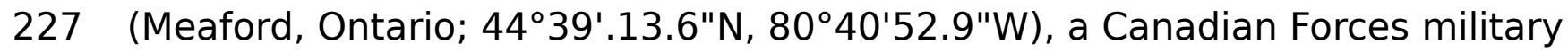

228 base approximately $165 \mathrm{~km}$ northeast of Guelph. So far as we are aware, this

229 site was isolated from any crops grown from seeds treated with

230 neonicotinoids by approximately $10 \mathrm{~km}$. At the LFCATF apiary, colonies from

231 control fields were separated from colonies from clothianidin-treated fields by

232 approximately $40 \mathrm{~m}$, and intra-treatment colonies were approximately $2 \mathrm{~m}$

233 from each other. No other colonies were present at or near to the LFCATF

234 apiary. At this site bees foraged on a variety of wildflowers.

235 In September 2012, after bloom of agricultural crops in southern

236 Ontario was finished, colonies were again prepared and moved at night from

237 the LFCATF apiary to a winter apiary located at the University of Guelph -

238 Arkell Agricultural Research Station. Once at the fall/winter apiary, all

239 colonies received medication (e.g., antibiotics), and treatments for Varroa

240 mite and tracheal mites, based on results of the fall pest and disease

241 assessments. Beginning 2 October 2012, colonies were fed via hive-top

242 feeders. Each feeder was initially filled with approximately $2 \mathrm{~L}$ of sugar

243 solution (2:1 sugar/water). The feeders were checked at intervals of

244 approximately 3-4 days and refilled as needed. Colony bottom entrances

245 were reduced, an upper entrance provided, and insulation placed between

246 the inner cover and lid in mid-October. Feeders were all removed 26 October 
247 and on 15 November colonies were wrapped with insulation for protection

248 against subfreezing temperatures.

\section{Colony Endpoint Measures}

250 Weight Gain

251 Using a tripod-mounted, certified scale, colonies were weighed after dark on

252 the night they were transported to canola fields and again after dark on the

253 night of transport to the LFCATF apiary.

\section{Honey Yield}

255 Honey yield per colony was determined by weighing empty honey supers

256 containing empty frames with foundation, before placement on colonies and

257 weighing them again after removal from colonies. Honey supers were

258 labeled to allow cross-referencing to the colony from which the super was

259 removed. Supers were removed from colonies when full of honey and

260 replaced with empty supers as needed throughout the study. The sum of all

261 honey super yields for a given colony equaled the total honey yield for that

262 colony over approximately a 3.5-month period.

\section{Adult Mortality}

264 Colony adult mortality was measured in each hive using drop zone dead bee 265 (DZDB) traps (Rogers, Williams \& Bins, 2009), a $50 \times 100 \mathrm{~cm}$ wood frame 266 with fine mesh wire screening on the bottom and coarse mesh on the top, 267 positioned at the hive entrance. The DZDB trap was a modification of a trap 
268 originally described by Porrini et al. (2003). Dead worker and drone bees

269 were removed from the traps and counted twice weekly during the period

270 colonies were in the study fields. Collections were made early in the week

271 and again late in the week so that duration between collections was 3 or 4

272 days. If available after counting, for one dead bee assessment per week,

273 approximately $10 \mathrm{~g}$ of collected dead bees from each colony were pooled by

274 field to produce a $40 \mathrm{~g}$ sample, and then placed in a brown glass jar, labeled,

275 and stored frozen at $\leq-10^{\circ} \mathrm{C}$. Bee samples were later shipped to the USDA-

276 APHIS National Research Center, Gastonia, NC for clothianidin residue

277 analysis.

278 Brood Assessments

279 Brood assessments were conducted on Day -4 , prior to movement of colonies

280 to the canola fields, and at least twice while colonies were in canola (Days 7

281 and 14). In addition, assessments were conducted approximately every 21

282 days at the fall and winter apiaries until mid-October, and again in the spring

283 of 2013.

284 During each colony assessment, presence or absence of eggs and 285 unsealed larvae was determined visually and noted. The number of sealed 286 brood cells on all frames was determined for all colonies. After doing adult 287 strength assessments (see below), adult bees were shaken and brushed off 288 frames into the brood box. The number of sealed brood cells on 9 frames per 289 colony (i.e., two sides per frame) was captured as digital images using Canon 290 EOS 5D Mark II digital cameras with $100 \mathrm{~mm}$ Macro lenses and portable fabric 
291 light-boxes, which facilitated consistent lighting during the image collections.

292 A camera-mounting device that also contained a pivoting frame rack was

293 placed into the light box. Colony frames were set on the rack while images

294 were recorded. This mounting device facilitated an exact focal length for

295 every digital image collected. The digital cameras were computer-controlled

296 (laptop PC) and collected images were automatically stored on the camera

297 memory card and simultaneously downloaded to the laptop PC hard drive in

298 the field as a back-up precaution. Collected digital images were downloaded

299 to at least one secondary electronic data storage media once the equipment

300 was returned to the laboratory.

301 Digital images were analyzed using IndiCounter ${ }^{\circledR}$, Version 2.3, digital

302 image analysis software (WSC Scientific Heidelberg, Germany). The analysis

303 software counted the number of sealed brood cells per frame. High accuracy

304 of the counting software was verified by comparing values obtained on 100

305 randomly selected images (frames) to manual counts of cells from those

306 images; the difference in counts with the software and manual counts was an

307 average of $\pm 1.00 \%$ ( 42 cells per frame; $t$-test, $P=0.82$ ). The quantified

308 values for number of sealed brood cells per frame were used to calculate

309 total sealed brood cells per colony.

\section{Adult Strength Assessments}

311 Adult strength assessments were conducted and verified concurrently with

312 the brood production assessments using the methodology and equipment

313 described for sealed brood. Digital images were acquired with adult bees 
314 present on both sides of each brood frame in each colony. The raw images

315 were transferred to a laptop PC in the field and copied again to a second data

316 storage media in the laboratory. The IndiCounter software identified and

317 counted individual bees on each frame and these numbers were used to

318 calculate total number of bees at the hive at the time of the assessment.

319 Spring 2013 Colony Assessments

320 Between 20 and 25 May 2013, when temperatures were $\geq 15^{\circ} \mathrm{C}$ and there

321 was no heavy rainfall, the following data were collected: determination of

322 dead and live colonies; capped brood assessment with digital imagery; adult

323 strength assessment with digital imagery; determination of presence of

324 queen, eggs and larvae; and collection of beeswax and bee samples for

325 Varroa mite, tracheal mite, and Nosema spore counts. Methods used were as 326 described above.

\section{Sample Collection}

328 Nectar, honey, pollen, and beeswax were collected from colonies at each field

329 (samples from four colonies pooled by field) on Day -4 (except pollen), 7, and

33014 , seven days after movement of colonies to the LFCATF apiary, and

331 thereafter at approximately 21-day intervals. Nectar and honey were

332 collected until mid-October, and the final pollen samples were taken on 18

333 September. The final beeswax samples in autumn 2012 were collected 21

334 September, and beeswax samples were again collected on 20-25 May during 
335 the spring 2013 colony assessment. Collections on Day 84 occurred over 3

336 days $(17,18,21$ September, 2012) due to inclement weather.

337 Nectar that was freshly deposited in wax cells of the brood box or

338 honey supers, was extracted using a new disposable pipette or syringe, or by

339 gently shaking a brood frame over a large piece of wax paper and pouring

340 the expelled nectar off the paper into a labeled brown Nalgene or glass jar (5

$341 \mathrm{~g}$ samples). Honey (5 g samples) from capped cells was collected using new

342 disposable spatulas or syringes placed in a labeled brown Nalgene or glass

343 jar. Areas of approximately $3 \mathrm{~cm}^{2}$ of food-free beeswax were collected from

344 honey supers and placed in labeled capped Nalgene vials or $50 \mathrm{ml}$ centrifuge

345 tubes with screw caps. Pollen was collected using ANEL STANDARD ${ }^{\circledR}$ pollen

346 traps. On each collection day, the traps were active for $24 \mathrm{~h}$ prior to

347 collection. Pollen samples from each hive on each collection day were

348 separately placed in labeled sealable plastic bags, and subsequently

349 transferred to labeled brown Nalgene or glass jars in the laboratory. For each

350 date, equal portions of pollen from each hive were combined to make a

351 pooled sample of at least $15 \mathrm{~g}, 10 \mathrm{~g}$ of which was used for pesticide residue

352 analysis (including enough for back-up samples), with the remaining $5 \mathrm{~g}$ of

353 pollen used for floral source analysis. When in the field, all samples were

354 immediately placed on ice or frozen ice substitute in a cooler, and placed in a

355 freezer at $\leq-10^{\circ} \mathrm{C}$ when returned to the laboratory the same day.

356 Pollen Source Analysis

357 Subsamples of pollen collected from pollen traps were used to determine the 
358 percent composition, by flower type, of the pollen collected by honey bees

359 when in canola fields and when in the LFCATF apiary site. Flower samples

360 from flowering crops or wild flowers observed in the vicinity of the study

361 fields were photographed, collected and dried in small, labeled, paper

362 envelopes periodically during the study. The floral samples and photographs

363 were used as reference checks for the pollen analysis.

\section{Residue Analysis}

365 Nectar, pollen, honey, beeswax, and dead bee samples, previously frozen,

366 were packed on frozen gelpacks and delivered to the USDA-APHIS National

367 Science Laboratory, Gastonia, NC for analysis. Residue analysis for pollen,

368 honey, nectar and beeswax was initially performed using a broad pesticide

369 screening method (LOD for clothianidin $=1.5 \mathrm{ppb}$ ). Because agricultural

370 commodities have complex matrices that can interfere with analytical

371 procedures for detecting pesticide residues or other analytes, an extraction

372 procedure was used to improve the detection of pesticide residues. Samples

373 were extracted for pesticide residue analysis using method AOAC 2007.01

374 (AOAC, 2007). This method utilizes the QuEChERS (Quick, Easy, Cheap,

375 Effective, Rugged, and Safe) approach to reduce sample suppression or

376 enhancement effects that matrices may create during chromatographic

377 analysis. Analytes of interest were extracted from samples by high-speed

378 grinding in an acidified acetonitrile and water mixture followed by a "clean-

379 up" to remove some matrix components and filtration to remove particulates.

380 Separate aliquots of extract were analyzed for pesticide residue by gas 
381 chromatography (GC) and liquid chromatography (LC) techniques utilizing

382 mass selective detection systems. A total of 70 honey and nectar samples,

38380 beeswax samples, 20 dead bee samples, and 60 pollen samples were

384 analyzed using this method.

385 After the screening analyses were complete, personnel at the Gastonia

386 USDA lab analyzed back-up aliquots of the same nectar and pollen samples

387 using an analytical method specifically for detecting clothianidin residues

$388(\mathrm{LOQ}=1.0 \mathrm{ppb}, \mathrm{LOD}=0.6 \mathrm{ppb})$. To improve detection sensitivity for

389 clothianidin, extraction procedures were used according to Kamel (Kamel,

390 2009). Analytes of interest were extracted from samples by high-speed

391 grinding in a mixture of high purity acetonitrile, water, and triethyl amine

392 followed by a "clean-up" procedure. Separate aliquots of extract were

393 analyzed for clothianidin and metabolite residues by LC techniques utilizing

394 mass selective detection systems.

395 Any nectar and pollen sample materials remaining, after the two USDA

396 analyses, were transported to Bayer CropScience (BCS) in Research Triangle

397 Park, North Carolina, where they were again analyzed for presence and

398 quantitation of clothianidin residues using a more sensitive analytical method

$399(\mathrm{LOQ}=0.5 \mathrm{ppb} ; \mathrm{LOD}=0.35 \mathrm{ppb})$ (Billian \& Schoning, 2009).

\section{Data analysis}

$401 t$-tests were conducted to compare the effect of clothianidin seed-treatment 402 on levels of certain mites and diseases, colony weight gain, honey yield, 403 overall pollen collection, and overwinter survival. Data on the number of 
404 dead bees, adults, sealed brood cells, and residues in pollen were analyzed

405 using repeated measures multivariate analysis of variance using the standard

406 least squares fit model platform (Manova) in JMP (SAS, 2012) with treatment

407 as the fixed effect and time as the repeated (random) effect. Assumptions of

408 normal distribution of the error term and homogeneity of variance were met

409 for all analyses. For these data, pseudo-replication was avoided by using a

410 single datum (mean of the sub-samples) for each experimental unit (Hurlbert,

411 1984; Whitlock \& Schluter, 2009). Spring 2013 Nosema spore count data

412 were analyzed using a multivariate standard least squares model

413 incorporating fixed factors of treatment and colony survivorship (i.e. colonies

414 that were classified as dead or alive). Nosema data were square-root

415 transformed before analysis to fulfill normality assumptions. Unless stated

416 otherwise, values are presented as means \pm standard deviation. All data

417 analyses were done using JMP software (SAS, 2012).

\section{RESULTS}

\section{Pests and Diseases 2012}

420 Counts of Varroa mites were low in our colonies. There was no difference in

421 Varroa mite levels of control and treatment colonies before exposure to

422 clothianidin, and although the number of mites per 100 bees increased while

423 in canola fields, there was no effect of treatment (Table 1). The number of

424 mites per 100 bees was at or below threshold levels of two and three mites

425 per 100 bees for early and late summer, respectively, as recommended by

426 the Ontario Beekeepers' Association (2012) for both control (June: $0.74 \pm$ 
4270.58 mites/100 bees; Aug: $2.40 \pm 0.77$ mites/100 bees) and treatment (June:

$4280.49 \pm 0.41$ mites/100 bees; Aug: $2.97 \pm 2.15$ mites/100 bees) colonies.

429 Nosema counts were also low in summer 2012. Samples from most

430 control (12/20) and treatment (14/20) colonies had no Nosema spores

431 detected and the mean number of spores per bee from control (195,000 \pm

$432432,450)$ and treatment $(122,500 \pm 269,002)$ colonies was not significantly

433 different $\left(t_{8}=0.63, P=0.53\right)$. None of the treated or control hives showed

434 any presence of AFB or EFB, and incidence of chalkbrood was generally very

435 low. In June 2012, the incidence of tracheal mite exceeded the

436 recommended threshold of 10\% infestation (OMAFRA, 2013a) in six control

437 colonies and five treatment colonies. The tracheal mite threshold was not

438 exceeded for any control or treatment colony samples taken in late July, 4392012.

\section{Colony Weight Gain and Honey Yield 2012}

441 There was no difference in mean weight between control $(27.9 \pm 1.7 \mathrm{~kg})$ and 442 treatment $(28.9 \pm 1.5 \mathrm{~kg})$ colonies when initially placed in canola fields, or in

443 weight gain when removed from fields for transport to the LFCATF apiary

444 (control: $14.7 \pm 5.5 \mathrm{~kg}$; treatment: $14.2 \pm 4.0 \mathrm{~kg}$ ). There was also no

445 difference in honey yield from colonies in control $(51.0 \pm 14.7 \mathrm{~kg})$ or

446 treatment $(52.9 \pm 12.5 \mathrm{~kg})$ fields (Table 1$)$.

\section{Number of Dead Bees, Adults and Sealed Brood 2012}


448 The number of dead bees collected in front of hives did vary over time, but

449 was not influenced by treatment (Table 1; Fig. 1). Exposure to clothianidin

450 seed-treated canola had no effect on the number of adults per colony, which

451 did not change over time. The effect of time on adults was the same for both

452 control and treatment colonies (Table 1; Fig. 2A). Similarly, the number of

453 sealed brood cells per colony was not affected by treatment, although the

454 number was reduced in the fall as queens ceased egg laying in preparation

455 for overwintering (Table 1; Fig. 2B).

\section{Pollen Collection 2012}

457 Honey bees foraged heavily on canola the first week of their introduction to

458 canola fields (Table S1). Canola pollen accounted for $88 \%$ of total pollen

459 recovered from pollen traps on Day 7 (control: $84.9 \pm 15.2 \%$; treatment: 91.0

$460 \pm 6.2 \%)$. The amount of canola pollen collected did not differ among

461 treatment and control fields (Table 1), but foraging on canola dropped sharply

462 toward the end of week two (Table 1), with only $46 \%$ of the total being canola

463 pollen on Day 14 (Table S1; control: $37.5 \pm 43.3 \%$; treatment: $54.8 \pm 46.0 \%$ ).

464 All other pollen recovered in pollen traps was from wild flowers or

465 ornamentals (Table S2) with the exception of corn (Zea mays L.), which was

466 recovered from some colonies in control and treatment fields in small

467 amounts in week two (Day 14 ; range $=0-7 \%$ of total pollen content; mean $=$

$4681.3 \%$ of total pollen content). Field treatment also had no effect on daily

469 pollen collection per colony during or after their placement in canola fields

470 (Fig. 3), or on the total pollen collected from hives during the experiment 
471 (Table 1; control: $827 \pm 187 \mathrm{~g}$; treatment: $688 \pm 41 \mathrm{~g}$ ). There was a

472 significant effect of time on the amount of pollen collected (Table 1), with an

473 increase in pollen recovered from pollen traps on day 42 when colonies were

474 in the LFCATF apiary (Fig. 3). After honey bee colonies were removed from

475 canola fields and placed in the LFCATF apiary, no canola, corn, or soybean

476 pollen, nor pollen from any other crop, was recovered from pollen traps.

\section{Spring Assessment 2013}

478 One colony from a control field and one from a treatment field died prior to

479 overwintering. In both cases the queen disappeared from the colonies. After

480 several weeks of monitoring, the colonies remained queenless, with no

481 supercedure cells, no eggs and no larvae. These conditions defined a "dead"

482 colony. Of the 19 control colonies that were alive going into winter, 7 were

483 classified as "dead" the following April (37\% overwinter colony loss). Fewer

484 colonies from treatment fields died over the winter ( 5 of $19=26 \%$ overwinter

485 colony loss), but clothianidin seed-treatment had no statistically significant

486 effect on percent colony mortality (Table 1). Two additional control colonies,

487 and one additional treatment colony, which were noted to be weak in April,

488 died between the April assessments and the final colony assessments made

489 during 20-25 May.

490 Among live colonies, there was no difference in the number of adults

491 (control: $8069 \pm 5317$ individuals; treatment: $6834 \pm 4005$ individuals) or

492 capped brood cells (control: $6438 \pm 5657$ cells; treatment: $4968 \pm 3617$

493 cells) in spring 2013 (Table 1). Varroa mite counts were very low, with less 
494 than one mite per 100 bees detected in all colonies. Incidence of tracheal

495 mite was low. There was a single control colony with a $2 \%$ infestation level,

496 and a single treatment colony with a $2 \%$ infestation; all other colonies had no

497 tracheal mite detected. AFB and EFB were not detected in any colony, and

498 chalkbrood was only detected on two frames of a single hive. Low incidence

499 (3-4 larvae) of wax moth (Galleria melonella L.) larvae was detected in two

500 colonies.

501 Because no live bees could be sampled from dead colonies, Nosema

502 analysis was conducted on dead bees from dead colonies, whereas Nosema

503 analyses for living hives were conducted on live bees. Whether colonies were

504 from treated or control fields had no effect on the number of spores per bee,

505 but the number of Nosema spores recovered from bees from dead colonies

$506\left(2.2 \times 10^{7} \pm 2.5 \times 10^{7}\right.$ spores/bee $)$ was almost a full order of magnitude

507 higher than Nosema levels in live colonies $\left(4.9 \times 10^{6} \pm 7.0 \times 10^{6}\right.$ spores/bee $)$

508 (Table 1). The number of spores in live control colonies $\left(6.5 \times 10^{6} \pm 8.3 \times 10^{6}\right.$

509 spores/bee) was similar to that in live treatment colonies $\left(3.5 \times 10^{6} \pm 5.6 \times\right.$

$51010^{6}$ spores/bee $)\left(t_{24}=-1.20, P=0.24\right)$.

\section{Residue Analysis}

512 Analysis of nectar, honey, and beeswax samples by the USDA-APHIS National

513 Science Laboratory resulted in no detection of clothianidin in these matrices

$514(\mathrm{LOQ}=1.0 \mathrm{ppb}$; LOD $=0.6 \mathrm{ppb})$. The USDA Laboratory analysis of pollen

515 collected from pollen traps detected quantifiable levels of clothianidin in only

516 one sample from control fields ( $1.5 \mathrm{ppb})$ and one sample from treatment 
517 fields ( $1.1 \mathrm{ppb})$. Trace amounts less than the LOQ (1.0 ppb) were detected in

518 one other control pollen sample, and one other treatment pollen sample.

519 Detections from treatment fields were from samples collected the first week

520 colonies were in canola, whereas clothianidin detections in control fields were

521 from samples collected from colonies during the second week.

522 Enough pollen sample material was available to have the BCS Residue

523 Analysis Laboratory analyze pollen samples with a more sensitive method

$524(\mathrm{LOQ}=0.5 \mathrm{ppb} ; \mathrm{LOD}=0.35 \mathrm{ppb})$. There were no detections of clothianidin in

525 pollen collected from traps seven days after placement of hives in control

526 fields ( 0 detections from 5 samples), but samples collected at this time from

527 each of the five treatment fields had quantifiable clothianidin residues at

528 levels of $0.6,0.8,1.0,1.1$, and $1.1 \mathrm{ppb}$. For pollen samples collected 14 days

529 after placement in canola fields, quantifiable residues of clothianidin were

530 found in four of five treatment samples $(0.5,0.6,0.8$, and $1.9 \mathrm{ppb})$, and two

531 of five control samples ( 0.5 and $1.3 \mathrm{ppb})$. One additional Day 14 control

532 sample had a detectable, but unquantifiable residue of clothianidin $(0.38$

$533 \mathrm{ppb})$. Analyses of samples from all matrices collected after colonies were

534 moved out of canola fields to the LFCATF had no detections of clothianidin.

535 Over the two weeks of exposure of colonies in canola fields, the amount

536 of clothianidin in the pollen from control colonies was significantly lower than

537 that from colonies in treatment fields, but there was no significant effect of

538 time or the treatment-time interaction (Table 1). Over both sampling periods,

539 mean clothianidin residues in colonies from control fields $(0.24 \pm 0.44 \mathrm{ppb})$ 
540 were over 3 -fold lower than residues in colonies from treatment fields $(0.84 \pm$

$5410.49 \mathrm{ppb})$.

$542 \quad$ Although a number of other pesticides were detected in various

543 matrices from control and treatment hives, most of the 173 pesticides

544 included in the broad screen conducted by the USDA-APHIS National Science

545 Laboratory were not detected (Table 2). The acaricides coumaphos (or its

546 oxon), fluvalinate, 2,4-dimethylphenyl formamide (the main metabolite of

547 amitraz), and thymol, and the fungicide chlorothalonil, were detected

548 relatively often in beeswax, and far less often in nectar, pollen, honey, and

549 dead bees. Other pesticides were detected rarely or in trace amounts (below 550 the LOQ) (Table 2).

\section{DISCUSSION}

552 The study results suggest that exposure to canola grown from clothianidin-

553 treated seed had no adverse effect on honey bee colonies. There were no

554 significant differences between colonies placed at treatment sites in

555 comparison to control sites for hive weight gain and honey production. Our

556 average honey yields of $50+\mathrm{kg} /$ colony (produced over a 3.5 month period)

557 were higher than the $2012(37.2 \mathrm{~kg})$ and 5-year $(37.7 \mathrm{~kg})$ honey yield

558 averages (produced over a 5-6 month period) for Ontario (OMAFRA, 2013b).

559 Considering the normal turn-over rate of bees in a healthy colony (Winston,

560 1987), and high recovery rate of dead bees previously recorded with DZDB

561 traps (Rogers et al., 2009), the number of dead bees we recorded in front of

562 hives in this study was low and normal. Likewise, adult strength (number of 
563 adult bees) and amount of sealed brood over the course of summer and

564 autumn 2012 and spring 2013 did not differ between treatments. With the

565 exception of one control and one treatment colony that died during the

566 summer (likely as a result of queen loss, which is not unusual given the

567 intense data collection and transport of the colonies), all colonies performed

568 very well during the summer and autumn.

569 Overwintering success likewise did not differ significantly between

570 treatment and control colonies. Winter colony loss rates were higher than

571 expected, at $37 \%$ for control and $26 \%$ for treatment colonies, but overall

572 (32\%) were similar to overwintering colony loss rates reported for the winter

573 of 2012-2013 for beekeepers in Ontario (38\%) and Canada as a whole (29\%)

574 (CAPA, 2013). Disease incidence was low during the summer, and Varroa

575 mite levels were low for the duration of the study. However, 10-fold more

576 Nosema spores were detected in bees from dead colonies than live colonies

577 in spring 2013. Although we did not measure Nosema loads in dead bees

578 from colonies that survived overwinter, these results suggest that there may

579 be a correlation between overwintering survival and Nosema infection in our

580 experiment. Colonies with high infection of $N$. apis may not survive winter,

581 and those that do typically have poor spring build-up (Pernal \& Clay, 2013).

582 We did not observe high levels of other pests, diseases, or viruses that cause

583 obvious external symptomologies (e.g., deformed wing virus, sacbrood) in

584 control or treatment colonies during our 2012 or spring 2013 assessments.

585 Currie et al. (2010) suggested that direct and indirect effects associated with

586 failure to control Varroa mites is the main cause of increased rates of winter 
587 colony losses in Canada, but that weather, fall feeding management,

588 presence of Nosema spp., viruses and other diseases, and spring build-up of

589 colonies, also contribute to high overwinter mortality.

$590 \quad$ Pollen trapped at hive entrances revealed a high use of the canola

591 study fields by foraging bees. The percentage of canola pollen in traps was

592 high (88\% during peak bloom) and there was no other canola available within

$59310 \mathrm{~km}$ of each study field. During week two, the use of some of the study

594 fields by pollen foragers, as indicated by the proportion of canola pollen

595 collected in traps, declined sharply. This is not unexpected as honey bees

596 have complex diet requirements (Haydak, 1970) and as generalists are

597 known to utilize a wide variety of pollen and nectar sources (Winston, 1987).

598 Workers expand their foraging range as they become more familiar with their

599 surroundings, and can rapidly change their foraging patterns in response to

600 changes in colony pollen requirements, with old floral patches being

601 abandoned for new more favored floral resources as they are discovered

602 (Seeley, 1985; Visscher \& Seeley, 1982; Winston, 1987).

603 Residue analysis indicated that honey bees were exposed to low levels

$604(0.5-1.9 \mathrm{ppb})$ of clothianidin in pollen. These amounts are comparable to

605 clothianidin residue levels detected in pollen from seed-treated crops in other

606 studies (Blacquière et al., 2012; EFSA, 2012a). These levels would not be

607 expected to cause adverse effects based on the previously confirmed No

608 Observable Adverse Effects Concentration (NOAEC) of 20 ppb (Schmuck \&

609 Keppler, 2003). We did not detect clothianidin residues in nectar, honey, or

610 beeswax. Several other studies have reported clothianidin residues in these 


\section{PeerJ Reviewing Manuscript}

611 matrices when honey bee colonies were placed in or adjacent to clothianidin

612 seed-treated canola. However, residues levels in these matrices are

613 generally lower than those detected in pollen, and often residues are not

614 detected at all in these matrices (Blacquière et al., 2012; Cutler \& Scott-

615 Dupree, 2007; EFSA, 2012a; EFSA, 2012b; Mullin et al., 2010; Pilling et al.,

616 2013; Walters, 2013).

617 Extensive efforts were made to isolate control sites from treatment

618 sites, by locating fields at least $10 \mathrm{~km}$ from each other. This was done to

619 avoid movement of foragers between treatment and control fields, which we

620 experienced in a previous experiment (Cutler \& Scott-Dupree, 2007).

621 Nevertheless, low levels of clothianidin were detected in pollen samples

622 collected toward the end of the bloom (Day 14) from control sites 2, 3, and 6.

623 The source of clothianidin in pollen from these colonies is unclear. Given the

624 distance between experimental fields, it is highly unlikely that bees from

625 control fields foraged in our treated fields (Winston, 1987). It also seems

626 highly unlikely that residues in pollen were the result of carry-over in soil from

627 previous years; if this were the case, we would have expected to find

628 clothianidin residues in week 1 control pollen as well. All control sites were

629 planted before treatment sites, so there is no possibility of residues being

630 picked up on or dislodged from the seeding equipment. Control and

631 treatment seeds are also easily distinguished by color, and our records show

632 no mix-up occurred during planting. There is also no indication in our records

633 of contamination or mix-up during sample collection. 
634 Clothianidin detections from control colonies may have been a result of

635 bees foraging off-site during the end of canola bloom. This hypothesis is

636 supported by the fact that other fungicides and insecticides not used in our

637 experiment were detected in colony matrices (Table 2). Analysis of pollen

638 trap contents showed that bees continued to forage at a high rate on canola

639 in week two at control site 6 (86\% canola pollen; down from 98\% canola

640 pollen in week one at this site), but control sites 2 and 3 in week two only had

641 canola pollen percentages of $1 \%$, and $15 \%$, respectively. This indicates a

642 substantial amount of off-site foraging at these sites was occurring by the

643 end of week two. Samples from control sites 2, 3, and 6 had very low

644 proportions of corn pollen $(5.0 \%, 0 \%$, and $0 \%$, respectively), and soybean

645 pollen was not found in any of the pollen samples. Thus, it seems unlikely

646 that the source of clothianidin was from pollen of corn and soybean. The vast

647 majority of pollen from sites 2 and 3 during week 2 was from wild or

648 ornamental plants, and these pollens may have been contaminated with

649 clothianidin via sprays of thiamethoxam. Clothianidin is the major break-

650 down product of thiamethoxam, and soil applications (transplant-drip) or

651 foliar sprays of thiamethoxam can result in detections of clothianidin in pollen

652 and nectar (Dively \& Kamel, 2012). Actara ${ }^{\circledR} 25 W G(25 \%$ thiamethoxam) is

653 registered in Ontario for use against insect pests on a wide range of tree

654 fruits, berries, and vegetables. It is possible that sprays of thiamethoxam

655 drifted on to plants, which were subsequently foraged upon by bees from our

656 control colonies. Irrespective of the source of clothianidin in pollen from our

657 control colonies, our results illustrate the difficulty of conducting a perfectly 


\section{PeerJ Reviewing Manuscript}

658 controlled field study with free-ranging honey bees in real-world

659 agroecosystems. This is especially true when conducting experiments with

660 neonicotinoids, which are now widely used on a large number of crops and

661 commodities.

662 In summary, all colonies performed well during and after the exposure

663 period, and had overwintering success similar to colonies in Ontario and

664 Canada on the whole. Although various laboratory studies have reported

665 sublethal effects in individual honey bees exposed to low doses of

666 neonicotinoid insecticides, the results of the present study suggest that

667 foraging on clothianidin seed-treated crops, under realistic conditions, poses

668 low risk to honey bee colonies. Our results are not conclusive as low

669 concentrations of clothianidin were detected in some control pollen samples,

670 but the results are consistent with those of two previous honey bee field

671 studies with clothianidin seed-treated canola ( Cutler \& Scott-Dupree, 2007;

672 Scott-Dupree et al., 2001). All three studies have shown that honey bee

673 colonies placed during bloom in or next to canola fields grown from

674 clothianidin-treated seeds perform as well as colonies in fields not treated

675 with clothianidin, and as well as what is typical for honey bee colonies in

676 Ontario. The results are also in agreement with semi-field (field cage, Tier 2)

677 and field studies that have found that individual bees and colonies are not

678 adversely impacted when foraging on neonicotinoid seed-treated crops

679 (Nguyen et al., 2009; Pilling et al., 2013; Pohorecka et al., 2012; Schmuck \&

680 Keppler, 2003; Schneider et al., 2012; Tasei et al., 2001; Thompson et al.,

681 2013), and corroborate the experiences of beekeepers in western Canada 
682 who for more than a decade have been producing honey in agroecosystems

683 dominated by clothianidin seed-treated canola.

\section{ACKNOWLEDGEMENTS}

685 The floral source analysis was conducted by Johanne Parent (Laboratoire BSL,

686 Rimouski, QC). Tracheal mite and Nosema analyses were conducted by

687 Brenda Perrin (Cameron, ON). Seed treatment was led by Benjamin Eakers

688 (BCS). Site selection, planting, and management were overseen by Keith

689 Ardiel (BCS), and conducted by Scott Ditschun, Robyn Walsh, and Katie

690 Caldecott. We thank Paul Kelly, Apiary Supervisor at HBRF, and his support

691 staff for advice and technical support throughout this study. We thank the

692 beekeepers (from Canada and the US) and provincial and federal government

693 personnel who provided helpful suggestions on the study design during a

694 day-long field tour and open discussion at the University of Guelph in June

695 2012. Roger Simonds (USDA), and Gary Christensen and Audry Miller (BCS)

696 led the residue analysis component of this study. Data collection and field

697 assistance from Drew Mochrie, Daniel Thurston, Hilary Little, Cam Menzies,

698 Devon Hardy and Elaine Kennedy is gratefully acknowledged.

\section{REFERENCES}

700 AOAC. 2007. Pesticide Residues in Foods by Acetonitrile Extraction and

701 Partitioning with Magnesium Sulfate. AOAC International, Official

702 Methods of Analysis. Method No. AOAC 2007.01. 
703 Billian P, Schoning R. 2009. Analytical method 01131 for the determination of

704 residues of thiamethoxam and clothianidin in/on honey bees, nectar 705 (honey), pollen and flowers by HPLC-MS/MS. February 10, 2009. Bayer

$706 \quad$ CropScience Method Number: 01131.

707 Blacquière T, Smagghe G, van Gestel CAM, Mommaerts V. 2012.

708 Neonicotinoids in bees: a review on concentrations, side-effects and 709 risk assessment. Ecotoxicology 21:973-992.

710 Campbell PJ. 2013. Declining European bee health: banning the

711 neonicotinoids is not the answer. Outlooks on Pest Management 24:52-

71257.

713 CAPA. 2013. CAPA Statement on Honey Bee Wintering Losses in Canada

714 (2012). Canadian Association of Professional Apiculturists.

715 http://capabees.org/content/uploads/2012/10/2012capawintloss1.pdf.

$716 \quad$ Accessed 10 Sep 2014.

717 Cresswell JE. 2013. Environmental Audit Committee - Pollinators and

718 Pesticides: Written evidence submitted by Dr. James Cresswell,

719 University of Exeter.

$720 \quad$ www.publications.parliament.uk/pa/cm201213/cmselect/cmenvaud/668

$721 \quad$ 668we10.htm. Accessed 27 Sept 2013.

722 Cresswell JE, Thompson HM. 2012. Comment on "A Common Pesticide

723 Decreases Foraging Success and Survival in Honey Bees". Science

$724 \quad 337: 1453$.

725 Currie RW, Pernal SF, Guzmán-Novoa E. 2010. Honey bee colony losses in 726 Canada. J Apicult Res 49:104-106. 
727 Cutler GC, Scott-Dupree CD. 2007. Exposure to clothianidin seed-treated

728 canola has no long-term impact on honey bees. Journal of Economic $729 \quad$ Entomology 100:765-772.

730 Cutler GC, Scott-Dupree CD. 2014. A field study examining the effects of 731 exposure to neonicotinoid seed-treated corn on commercial bumble

732 bee colonies. Ecotoxicology:(in press; DOI: 10.1007/s10646-10014733 11340-10645).

734 Cutler GC, Scott-Dupree CD, Drexler DM. 2014. Honey bees, neonicotinoids 735 and bee incident reports: the Canadian situation. Pest Management $736 \quad$ Science 70:779-783.

737 Dively GP, Kamel A. 2012. Insecticide residues in pollen and nectar of a 738 cucurbit crop and their potential exposure to pollinators. Journal of $739 \quad$ Agricultural and Food Chemistry 60:4449-4456.

740 EFSA. 2012a. Scientific Opinion on the science behind the development of a 741 risk assessment of Plant Protection Products on bees (Apis mellifera, 742 Bombus spp. and solitary bees). EFSA Panel on Plant Protection 743 Products and their Residues (PPR). European Food Safety Authority 744 (EFSA), Parma, Italy. EFSA Journal 10:2668.

745 EFSA. 2012b. Statement on the findings in recent studies investigating sub746 lethal effects in bees of some neonicotinoids in consideration of the uses currently authorised in Europe. European Food Safety Authority. EFSA Journal 10:2752.

750

EPA. 1989. U.S. Environmental Protection Agency, Good Laboratory Practice Standards, 40 CFR Part 160 PP-300165A; FRL-3518-2, RIN 2070-AB68, 
751 Federal Insecticide, Fungicide and Rodenticide Act (FIFRA). Washington,

752 DC.

753 Gill RJ, Ramos-Rodriguez O, Raine NE. 2012. Combined pesticide exposure 754 severely affects individual- and colony-level traits in bees. Nature $755 \quad 491: 105-108$.

756 Haydak MH. 1970. Honey bee nutrition. Annual Review of Entomology $757 \quad 15: 143-156$.

758 Henry M, Beguin M, Requier F, Rollin O, Odoux JF, Aupinel P, Aptel J, 759 Tchamitchian S, Decourtye A. 2012. A common pesticide decreases 760 foraging success and survival in honey bees. Science 336:348-350.

761 Hurlbert SH. 1984. Pseudoreplication and the design of ecological field 762 experiments. Ecological Monographs 54:187-211.

763 Iwasa T, Motoyama N, Ambrose JT, Roe RM. 2004. Mechanism for the 764 differential toxicity of neonicotinoid insecticides in the honey bee, Apis 765 mellifera. Crop Protection 23:371-378.

766 Jeschke, Nauen R. 2008. Neonicotinoids - from zero to hero in insecticide 767 chemistry. Pest Management Science 64:1084-1098.

768 Kamel A. 2009. Refined methodology for the determination of neonicotinoid 769 pesticides and their metabolites in honey bees and bee products by 770 liquid chromatography - tandem mass spectrometry (LC-MS/MS).

771 Journal of Agricultural and Food Chemistry 58:5926-5931.

772 Matsuda K, Buckingham SD, Kleier D, Rauh JJ, Grauso M, Sattelle DB. 2001.

773 Neonicotinoids: insecticides acting on insect nicotinic acetylcholine 774 receptors. Trends in Pharmacological Sciences 22:573-580. 
775 Mullin CA, Frazier M, Frazier JL, Ashcraft S, Simonds R, vanEngelsdorp D,

776 Pettis JS. 2010. High levels of miticides and agrochemicals in North

777 American apiaries: Implications for honey bee health. Plos One

$778 \quad 5: e 9754$.

779 Nguyen BK, Saegerman C, Pirard C, Mignon J, Widart J, Tuirionet B, Verheggen

780 FJ, Berkvens D, De Pauw E, Haubruge E. 2009. Does imidacloprid seed-

781 treated maize have an impact on honey bee mortality? Journal of

$782 \quad$ Economic Entomology 102:616-623.

783 Nuyttens D, Devarrewaere W, Verboven P, Foqué D. 2013. Pesticide-laden

784 dust emission and drift from treated seeds during seed drilling: a

785 review. Pest Management Science 69:564-575.

786 OBA. 2012. Varroa Mites - Sampling and Monitoring Infestation Levels.

787 Ontario Beekeepers Association, factsheet.

788 http://www.ontariobee.com/sites/ontariobee.com/files/document/Copy-

789 of-varroa-sampling-EN.pdf. (accessed 20 Sep 2013).

790 OECD. 1999. Organization for Economic Cooperation and Development

791 Principles of Good Laboratory Practice (OECD Series on Principles of

792 Good Laboratory Practice and Compliance Monitoring, Number 1),

$793 \quad$ ENV/MC/CHEM (98) 17.

794 OMAFRA. 2013a. 2013 Ontario Treatment Recommendations for Honey Bee

795 Disease and Mite Control. Ontario Ministry of Agriculture and Food.

796 http://www.omafra.gov.on.ca/english/food/inspection/bees/2013-

797 treatment.pdf. (accessed 15 Nov 2013). 
798 OMAFRA. 2013b. Estimated Number of Beekeepers, Colonies of Bees,

799 Production and Value of Honey, 1982 to 2012. Ontario Ministry of

$800 \quad$ Agriculture and Food.

801 http://www.omafra.gov.on.ca/english/stats/hort/honey.htm. (accessed 80220 Sep 2013).

803 Pernal SF, Clay H. 2013. Honey Bee Diseases and Pests, $3^{\text {rd }}$ Ed. Beaverlodge, 804 AB: Canadian Association of Professional Apiculturists.

805 Pilling E, Campbell P, Coulson M, Ruddle N, Tornier I. 2013. A four-year field 806 program investigating long-term effects of repeated exposure of honey 807 bee colonies to flowering crops treated with thiamethoxam. Plos One 808 8:e77193.

809 PMRA. 2013. Pollinator Protection: Reducing Risk from Treated Seed. Health 810 Canada Pest Management Regulatory Agency. http://www.hc811 sc.gc.ca/cps-spc/pubs/pest/ fact-fiche/pollinator-protection812 pollinisateurs/index-eng.php. (accessed 27 May 3013).

813 Pohorecka K, Skubida P, Miszczak A, Semkiw P, Sikorski P, Zagibajlo K, Teper 814 D, Koltowski Z, Skubida M, Zdanska D, Bober A. 2012. Residues of 815 neonicotinoid insecticides in bee collected plant materials from oilseed 816 rape crops and their effect on bee colonies. Journal of Apicultural 817 Science 56:115-134.

818 Porrini C, Sabatini AG, Girotti S, Ghini S, Medrzycki SP, Grillenzoni F, Bortolotti 819 L, Gattavecchia E, G C. 2003. Honey bees and bee products as monitors 820 of the environmental contamination. APIACTA 38:63-70. 
821 Rogers R, Williams G, Bins M. 2009. Honey bee field study in melons treated

822 with Oberon ${ }^{\circledR}$ 2SC. Bayer CropScience Report No. EBBSY008-1.

823 SAS. 2012. JMP 10.0. SAS Institute, Cary, NC.

824 Schmuck R, Keppler J. 2003. Clothianidin: ecotoxicological profile and risk 825 assessment. Pflanzenschutz-Nachr Bayer 56:26-58.

826 Schmuck R, Schoening R, Stork A, Schramel O. 2001. Risk posed to

827 honeybees (Apis mellifera L., Hymenoptera) by an imidacloprid seed

828 dressing of sunfowers. Pest Management Science 57:225-238.

829 Schneider CW, Tautz J, Grunewald B, Fuchs S. 2012. RFID tracking of sublethal 830 effects of two neonicotinoid insecticides on the foraging behavior of $831 \quad$ Apis mellifera. Plos One 7:e30023.

832 Scott-Dupree C, Spivak M, Bruns G, Blenkinsop C, Nelson S. 2001. The impact 833 of Gaucho and TI-435 seed-treated canola on honey bees, Apis

834 mellifera L. Bayer Corporation Report No. 110403, EPA MRID No. $835 \quad 45422435$.

836 Scott-Dupree CD, Conroy L, Harris CR. 2009. Impact of currently used or 837 potentially useful insecticides for canola agroecosystems on Bombus 838 impatiens (Hymenoptera: Apidae), Megachile rotundata

839 (Hymentoptera: Megachilidae), and Osmia lignaria (Hymenoptera:

840 Megachilidae). Journal of Economic Entomology 102:177-182.

841 Seeley TD. 1985. Honeybee ecology. Princeton, NJ: Prinecton University Press.

842 Shimanuki H, Knox DA. 2000. Diagnosis of Honey Bee Diseases. USDA-ARS 843 Ag Handbook Number 690. 
844 Tasei JN, Ripault G, Rivault E. 2001. Hazards of imidacloprid seed coating to

845 Bombus terrestris (Hymenoptera: Apidae) when applied to sunflower.

$846 \quad J o u r n a l$ of Economic Entomology 94:623-627.

847 Thompson H, Harrington P, Wilkins W, Pietravalle S, Sweet D, Jones A. 2013.

$848 \quad$ Effects of neonicotinoid seed treatments on bumble bee colonies under

849 field conditions. Food and Environment Research Agency report.

$850 \quad$ http://www.fera.defra.gov.uk/scienceResearch/scienceCapabilities/chem

851 icalsEnvironment/documents/reportPS2371Mar13.pdf. (accessed 25

$852 \quad$ Mar 2014).

853 Visscher PK, Seeley TD. 1982. Foraging strategy of honeybee colonies in a 854 temperate deciduous forest. Ecology 63:1790-1801.

855 Walters K. 2013. Data, data everywhere but we don't know what to think?

$856 \quad$ Neonicotinoid insecticides and pollinators. Outlooks on Pest

$857 \quad$ Management 24:151-155.

858 Whitehorn PR, O'Connor S, Wackers FL, Goulson D. 2012. Neonicotinoid

859 pesticide reduces bumble bee colony growth and queen production.

$860 \quad$ Science 336:351-352.

861 Whitlock MC, Schluter D. 2009. The analysis of biological data. Greenwood 862 Village, CO: Roberts and Company Publishers.

863 Winston ML. 1987. The biology of the honey bee. Cambridge, MA: Harvard $864 \quad$ University Press. 
Table $\mathbf{1}$ (on next page)

Effects of exposure to clothianidin seed-treated canola on various honey bee colonies endpoints.

Effects of exposure to clothianidin seed-treated canola fields $(n=5)$ on various honey bee colony endpoints. Statistically significant effects $(\alpha=0.05)$ are highlighted in bold. 


\begin{tabular}{|c|c|c|}
\hline Endpoint & Effect measure & Statistics \\
\hline \multicolumn{3}{|l|}{ SUMMER 2012} \\
\hline Initial colony weight $(\mathrm{kg})$ & Treatment & $t_{8}=1.05, P=0.32$ \\
\hline $\begin{array}{l}\text { Weight gain in canola } \\
(\mathrm{kg})\end{array}$ & Treatment & $t_{8}=-0.18, P=0.87$ \\
\hline Honey yield (kg) & Treatment & $t_{8}=0.21, P=0.84$ \\
\hline Total pollen collected (g) & Treatment & $t_{8}=-1.63, P=0.17$ \\
\hline $\begin{array}{l}\text { Varroa mites per } 100 \\
\text { bees }\end{array}$ & $\begin{array}{l}\text { Treatment } \\
\text { Time } \\
\text { Treatment*Time }\end{array}$ & $\begin{array}{l}F_{1,8}=0.088, P=0.77 \\
F_{1,8}=15.54, P= \\
\mathbf{0 . 0 0 4 3} \\
F_{1,8}=0.60, P=0.46\end{array}$ \\
\hline $\begin{array}{l}\text { No. dead bees (per } 4 \\
\text { days) }\end{array}$ & $\begin{array}{l}\text { Treatment } \\
\text { Time } \\
\text { Treatment*Time }\end{array}$ & $\begin{array}{l}F_{1,8}=0.062, P=0.80 \\
F_{3,6}=11.29, P= \\
\mathbf{0 . 0 0 7} \\
F_{3,6}=2.94, P=0.12\end{array}$ \\
\hline No. adults & $\begin{array}{l}\text { Treatment } \\
\text { Time } \\
\text { Treatment*Time }\end{array}$ & $\begin{array}{l}F_{1,8}=0.24, P=0.20 \\
F_{6,3}=2.30, P=0.26 \\
F_{6,3}=3.12, P=0.19\end{array}$ \\
\hline No. sealed brood cells & $\begin{array}{l}\text { Treatment } \\
\text { Time } \\
\text { Treatment*Time }\end{array}$ & $\begin{array}{l}F_{1,8}=0.001, P=0.92 \\
F_{6,3}=9.35, P=\mathbf{0 . 0 4 7} \\
F_{6,3}=0.73, P=0.66\end{array}$ \\
\hline $\begin{array}{l}\% \text { canola pollen collected } \\
\text { by bees }\end{array}$ & $\begin{array}{l}\text { Treatment } \\
\text { Time } \\
\text { Treatment*Time }\end{array}$ & $\begin{array}{l}F_{1,8}=0.55, P=0.47 \\
F_{1,8}=9.89, P=\mathbf{0 . 0 1 4} \\
F_{1,8}=0.18, P=0.69\end{array}$ \\
\hline $\begin{array}{l}\text { Amount of pollen } \\
\text { collected daily }(\mathrm{g})\end{array}$ & $\begin{array}{l}\text { Treatment } \\
\text { Time } \\
\text { Treatment*Time }\end{array}$ & $\begin{array}{l}F_{1,8}=2.64, P=0.14 \\
F_{5,4}=6.80, P=\mathbf{0 . 0 4 4} \\
F_{5,4}=0.93, P=0.54\end{array}$ \\
\hline $\begin{array}{l}\text { Pollen clothianidin } \\
\text { residues }\end{array}$ & $\begin{array}{l}\text { Treatment } \\
\text { Time } \\
\text { Treatment*Time }\end{array}$ & $\begin{array}{l}F_{1,8}=7.62, P=\mathbf{P}=025 \\
F_{1,8}=0.60, P=0.46 \\
F_{1,8}=2.81, P=0.13\end{array}$ \\
\hline \multicolumn{3}{|l|}{ SPRING 2013} \\
\hline Overwinter mortality & Treatment & $t_{8}=-0.69, P=0.51$ \\
\hline No. adults & Treatment & $t_{8}=-0.41, P=0.69$ \\
\hline No. sealed brood cells & Treatment & $t_{8}=-0.49, P=0.64$ \\
\hline
\end{tabular}


Nosema counts

Treatment

$F_{1,1}=1.18, P=0.29$

Dead/Alive

$F_{1,1}=10.36, \boldsymbol{P}=$

Treatment*Dead/Alive

0.003

$F_{1,1}=0.02, P=0.89$ 
Table 2 (on next page)

Pesticides in honey bee colony matrices during and after exposure to canola grown from control or clothianidin-treated seed

Pesticide detections from different matrices during and after placement of honey bee colonies in canola fields grown from clothianidin-treated seed, or untreated seed. A total of 70 honey and nectar samples, 80 beeswax samples, 60 pollen samples, and 20 dead bee samples were analyzed. Detections reported at or above the limit of quantification are presented. 


\begin{tabular}{|c|c|c|c|c|c|c|c|c|c|c|c|c|c|c|c|}
\hline \multirow[t]{3}{*}{ Pesticide } & \multicolumn{15}{|c|}{ Detection and Mean or Max Concentration (ppb)* } \\
\hline & \multicolumn{3}{|c|}{ Pollen } & \multicolumn{3}{|c|}{ Nectar } & \multicolumn{3}{|c|}{ Honey } & \multicolumn{3}{|c|}{ Beeswax } & \multicolumn{3}{|c|}{ Dead bees } \\
\hline & $\begin{array}{l}\# \\
\text { positive } \\
(\%) \\
\end{array}$ & $\begin{array}{l}\text { me } \\
\text { an }\end{array}$ & $\begin{array}{l}\mathbf{m a} \\
\mathrm{x}\end{array}$ & $\begin{array}{l}\# \\
\text { positive } \\
(\%)\end{array}$ & $\begin{array}{l}\text { me } \\
\text { an }\end{array}$ & $\begin{array}{l}\mathbf{m a} \\
\mathbf{x}\end{array}$ & $\begin{array}{l}\# \\
\text { positive } \\
(\%)\end{array}$ & $\begin{array}{l}\text { me } \\
\text { an }\end{array}$ & $\begin{array}{l}\mathbf{m a} \\
\mathbf{x}\end{array}$ & $\begin{array}{l}\# \\
\text { positive } \\
(\%) \\
\end{array}$ & $\begin{array}{l}\text { me } \\
\text { an }\end{array}$ & $\begin{array}{l}\mathbf{m a} \\
\mathbf{x}\end{array}$ & $\begin{array}{l}\# \\
\text { positiv } \\
\text { e }\end{array}$ & $\begin{array}{l}\text { me } \\
\text { an }\end{array}$ & $\begin{array}{l}\mathrm{ma} \\
\mathrm{x}\end{array}$ \\
\hline Azoxystrobin $\S$ & $2(3.3)$ & 17.8 & $\begin{array}{l}18 . \\
6\end{array}$ & 0 & - & - & 0 & - & - & 0 & - & - & 0 & - & - \\
\hline Captan $\dagger$ & 0 & - & - & 0 & - & - & 0 & - & - & 0 & - & - & 0 & - & - \\
\hline $\begin{array}{l}\text { Chlorothalonil } \\
\dagger \ddagger\end{array}$ & 0 & - & - & 0 & - & - & 0 & - & - & $27(33.8)$ & 533 & $\begin{array}{l}106 \\
0\end{array}$ & $1(5.0)$ & 179 & $\begin{array}{l}17 \\
9\end{array}$ \\
\hline Chlorpyrifos † & 0 & - & - & 0 & - & - & 0 & - & - & 0 & - & - & 0 & - & - \\
\hline Coumaphos & $6(10.0)$ & 4.1 & 8.2 & $5(7.1)$ & 2.4 & 3.8 & 10 & 7.2 & $\begin{array}{l}54 . \\
8\end{array}$ & $69(86.3)$ & 133 & $\begin{array}{l}199 \\
0\end{array}$ & $6(30.0)$ & 3.3 & 5.9 \\
\hline Coumaphos & 0 & - & - & 0 & - & - & $1(1.4)$ & 7.6 & 7.6 & $69(86.3)$ & 30 & 123 & 0 & - & - \\
\hline $\begin{array}{l}2,4 \\
\text { Dimethylphenyl } \\
\text { formamide } \\
\text { (DMPF) }\end{array}$ & 0 & - & - & 0 & - & - & 0 & - & - & $14(17.5)$ & 39.3 & 87 & 0 & - & - \\
\hline Fluvalinate & 0 & - & - & 0 & - & - & 0 & - & - & $8(10.0)$ & 15.4 & $\begin{array}{l}26 . \\
9\end{array}$ & 0 & - & - \\
\hline Metolachlor † & 0 & - & - & 0 & - & - & 0 & - & - & 0 & - & - & 0 & - & - \\
\hline Pendimethalin $†$ & 0 & - & - & 0 & - & - & 0 & - & - & 0 & - & - & 0 & - & - \\
\hline Propanil & 0 & - & - & 0 & - & - & 0 & - & - & $1(1.3)$ & 99.7 & $\begin{array}{l}99 . \\
7\end{array}$ & 0 & - & - \\
\hline Propetamphos & 0 & - & - & 0 & - & - & $1(1.4)$ & 12.1 & $\begin{array}{l}12 . \\
1\end{array}$ & 0 & - & - & 0 & - & - \\
\hline Quinoxyfen & 0 & - & - & $1(1.4)$ & 18.6 & $\begin{array}{l}18 . \\
6\end{array}$ & 0 & - & - & 0 & - & - & 0 & - & - \\
\hline Thymol †‡ & $1(1.7)$ & 153 & $\begin{array}{l}15 \\
3\end{array}$ & 0 & - & - & 0 & - & - & $8(10.0)$ & 305 & 769 & 0 & - & - \\
\hline Trifluralin §† & 0 & - & - & 0 & - & - & 0 & - & - & 0 & - & - & 0 & - & - \\
\hline Vinclozolin $\ddagger$ & 0 & - & - & 0 & - & - & 0 & - & - & $3(3.8)$ & 13.6 & $\begin{array}{l}23 . \\
3\end{array}$ & 0 & - & - \\
\hline
\end{tabular}

* mean and max values for positive detections

$\S$ unquantifiable trace amounts detected in $\geq 1$ dead bee samples $\dagger$ unquantifiable trace amounts detected in $\geq 1$ pollen samples

$\ddagger$ unquantifiable trace amounts detected in $\geq 1$ beeswax samples 
Figure 1

Dead honey bees in front of colonies when in canola fields grown from control or clothianidin-treated seed.

Mean number of dead honey bees collected in front of colonies over 4 day intervals while in canola fields grown from seeds treated with or without (control) clothianidin ( $n=5$ fields per treatment). 


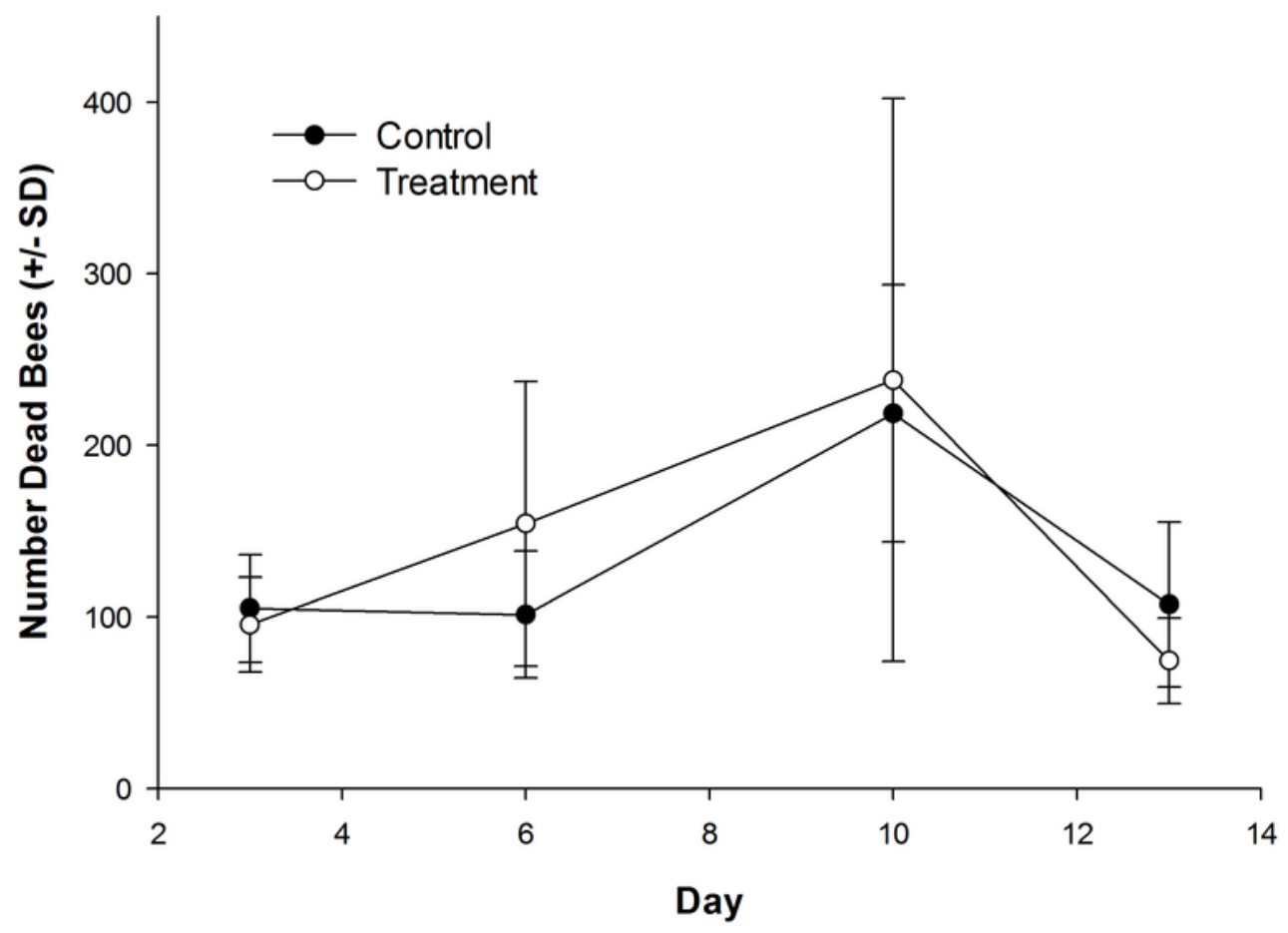


Figure 2

Number of honey bee adults and brood during and after exposure to canola grown from control or clothianidin-treated seed.

Mean number of $(A)$ adult honey bees and $(B)$ sealed brood cells in colonies during and after placement in canola fields grown from seeds treated with or without (control) clothianidin ( $n$ $=5$ fields per treatment). Colonies were in canola for 14 days and thereafter moved to an isolated apiary away from agricultural crops. 
A

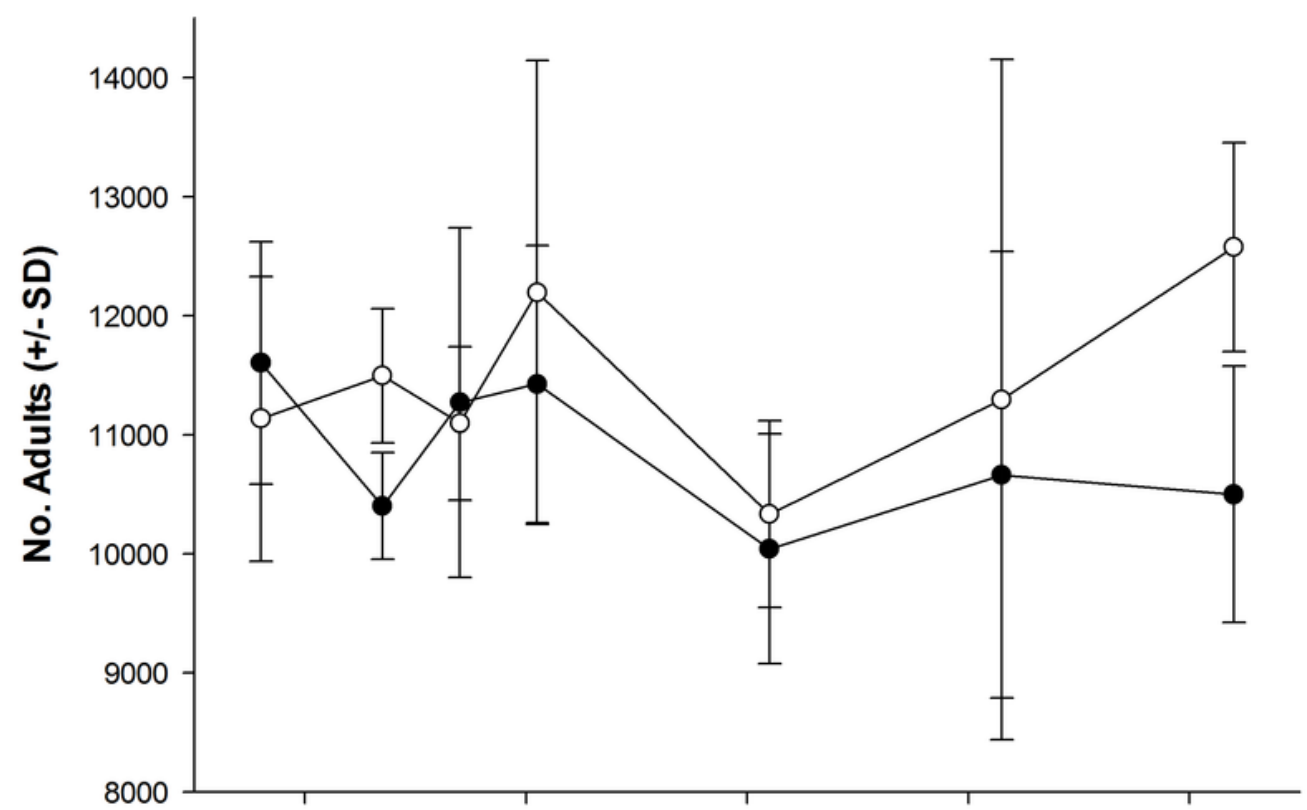

B

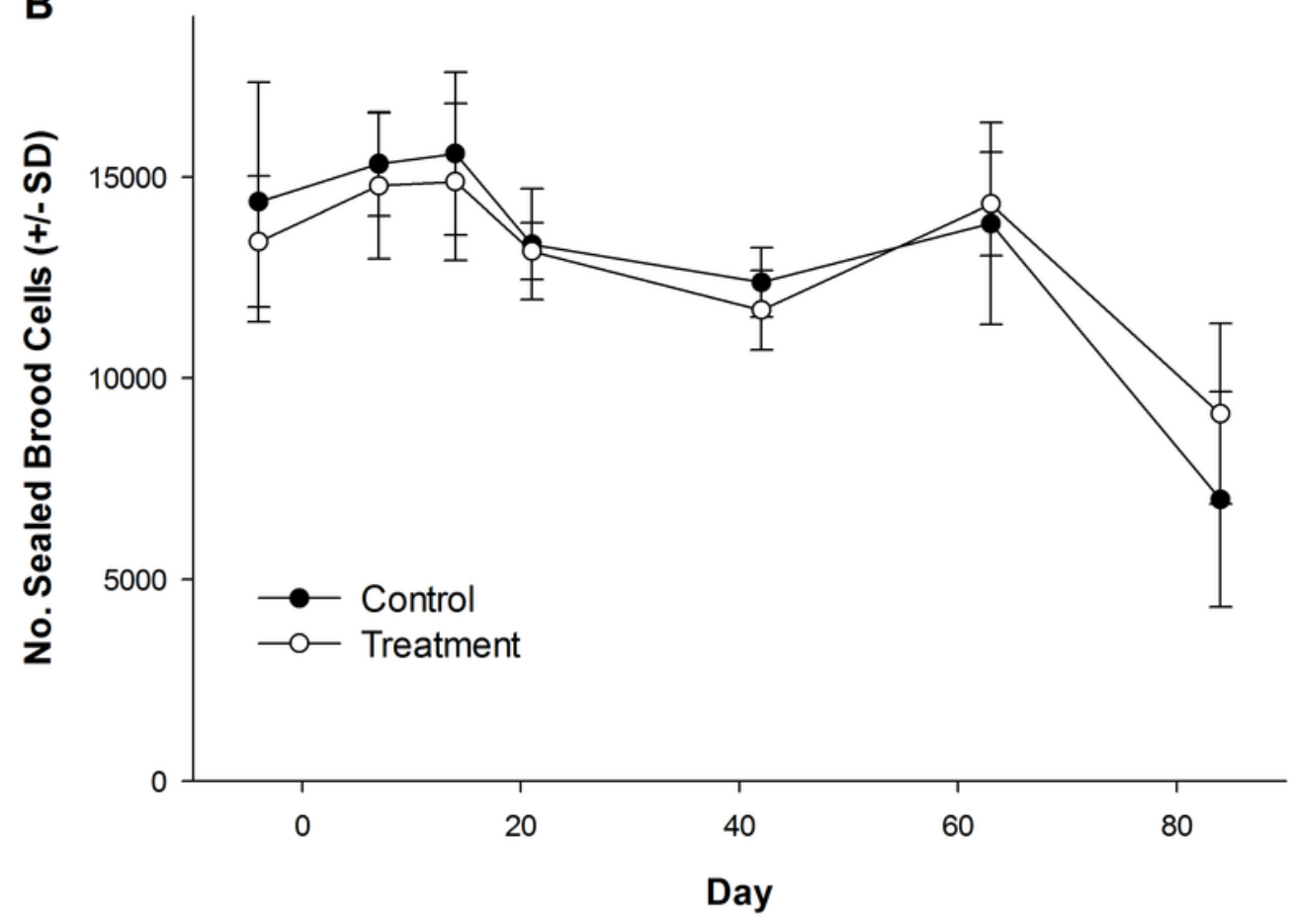


Figure 3

Pollen recovered from honey bee colonies during and after exposure to canola grown from control or clothianidin-treated seed.

Mean amount of pollen recovered from pollen traps on honey bee colonies during and after placement in canola fields grown from seeds treated with or without (control) clothianidin ( $n$ $=5$ fields per treatment). Colonies were in canola for 14 days and thereafter moved to an isolated apiary away from agricultural crops. 


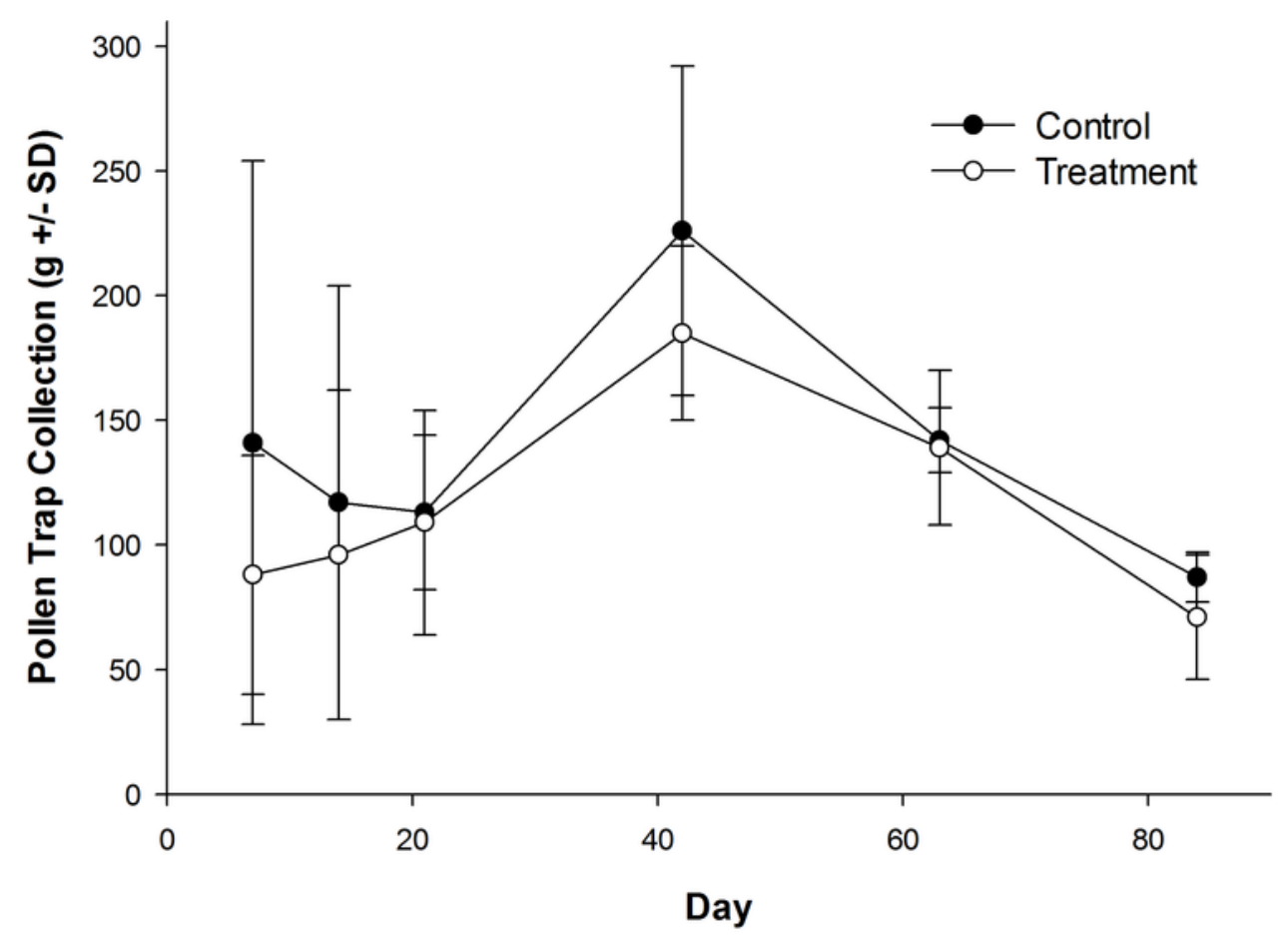

